\title{
1. Creative forces and institution building in international law
}

Rolf Einar Fife ${ }^{1}$

\section{INTRODUCTION}

The phrase 'the end of history' was the euphoric title of an article by the American political scientist Francis Fukuyama in the summer of 1989, before the dismantling of the Berlin Wall and the dissolution of the Soviet Union. ${ }^{2}$ Taking a largely Hegelian approach to the philosophy of history, the phrase came to signify that with the collapse of the Soviet Union the last ideological alternative to liberalism would be eliminated. ${ }^{3}$ This would entail a number of consequences for the evolution of world order. Irrespective of a largely critical reception of the phrase, the 1990s saw a quantum leap in the development of new international legal norms and institutions, notably with the establishment of the World Trade Organization, the United Nations Conference on Environment and Development in Rio de Janeiro, the entry into force of the United Nations Convention on the Law of the Sea, and the establishment of institutions of international criminal justice.

Following the end of the Cold War, unprecedented patterns of cooperation emerged also within the United Nations Security Council (UNSC). After the liberation of Kuwait in 1991 based on an authorization of use of force under Chapter VII of the Charter, the Council convened an extraordinary summit of Heads of State and Government in January 1992. ${ }^{4}$ It tasked the new

1 The author is alone responsible for the contents of this chapter, which does not represent a statement of positions of the Government of Norway.

2 F. Fukuyama, 'The End of History', The National Interest, no. 16, Summer 1989, pp. 3-18. This was followed by the author's best-selling book The End of History and the Last Man, New York: Free Press, 1992.

3 L. Menand, 'Francis Fukuyama postpones the end of history', The New Yorker, 27 August 2018, available at https://www.newyorker.com/magazine/2018/09/03/ francis-fukuyama-postpones-the-end-of-history.

4 UNSC Statement concerning the Council's Responsibility in the Maintenance of International Peace and Security, 3046th meeting, 31 January 1992, International Legal Materials, vol. 31(3), 1992, pp. 758-62. 
Secretary-General of the United Nations, Boutros Boutros-Ghali, to issue an 'analysis and recommendations on ways of strengthening and making more efficient within the framework and provisions of the Charter the capacity of the United Nations for preventive diplomacy, for peace-making and for peace-keeping'. 5

The resulting report An Agenda for Peace acknowledged the collapse of an 'immense ideological barrier that for decades gave rise to distrust and hostility' and called for a common 'will to take the hard decisions demanded by this time of opportunity' ${ }^{6}$ The report couched fundamental challenges in international legal terms:

The foundation-stone of this work is and must remain the State. Respect for its fundamental sovereignty and integrity are crucial to any common international progress. The time of absolute and exclusive sovereignty, however, has passed; its theory was never matched by reality. It is the task of leaders of States today to understand this and to find a balance between the needs of good internal governance and the requirements of an ever more interdependent world. Commerce, communications and environmental matters transcend administrative borders; but inside those borders is where individuals carry out the first order of their economic, political and social lives. The United Nations has not closed its door. Yet if every ethnic, religious or linguistic group claimed statehood, there would be no limit to fragmentation, and peace, security and economic well-being for all would become ever more difficult to achieve. ${ }^{7}$

The report spoke of the need for a 'balanced design', ensuring at the same time the stability of frontiers, the principle of self-determination for peoples and respect for democratic principles:

The sovereignty, territorial integrity and independence of States within the established international system, and the principle of self-determination for peoples, both of great value and importance, must not be permitted to work against each other in the period ahead. Respect for democratic principles at all levels of social existence is crucial: in communities, within States and within the community of States. Our constant duty should be to maintain the integrity of each while finding a balanced design for all. ${ }^{8}$

5 Statement by the President of the Council, section entitled 'Peace-making and peace-keeping', UN Doc. S/23500.

6 An Agenda for Peace: Preventive Diplomacy, Peace-Making and Peace-Keeping, Report of the Secretary-General pursuant to the statement adopted by the Summit Meeting of the Security Council on 31 January 1992, UN Doc. A 47/247, at para. 6.

7 Ibid., at para. 17.

8 Ibid., at para. 19. 
The expression 'established international system' referred to the consolidation of a universal legal system after decades of decolonization, including wars of national liberation, the Cold War and other centrifugal challenges to its unity. This body of law accumulated over time might have been seen by some as a mere consequence of irresistible winds of history. In ways unforeseen by Fukuyama in 1989 or 1992, this legal architecture and its institutions appear however, yet again, to be challenged. ${ }^{9}$ In this chapter I will reflect on three entirely disparate moments in the history of international law that have contributed to consolidating this 'established international system'. My focus will be on key mechanisms and creative forces for reception of international legal norms, concepts or patterns of thought.

\section{HOW STABILITY OF FRONTIERS IN THE FACE OF STATE SUCCESSION BECAME A BEDROCK OF MODERN INTERNATIONAL LAW}

Part of this acquis of international law is the coming of age and universalization of the objective of stability and finality of boundaries. ${ }^{10}$ While a sustained historical focus has been dedicated to other developments of international law, including human rights and international criminal law, less attention has been devoted to how the stabilization of frontiers came about, and to its contributions to the maintenance of international peace and security. Arguably, no phenomenon reflects this general thrust better than the gradual maturing and ultimately universal reception of the principle of uti possidetis juris, requiring newly independent states to respect inherited frontiers.

This principle was generated in Latin America in the nineteenth century, at a time when several European powers were engaged in colonial policies in Africa. ${ }^{11}$ A century later, it gained extraordinary momentum with the accept-

9 F. Fukuyama, Identity: The Demand for Dignity and the Politics of Resentment, New York: Farrar, Straus \& Giroux, 2018.

10 The expression 'stability and finality of frontiers' stems from a case concerning The Temple of Preah Vihear (Cambodia v. Thailand), Merits, Judgment of 15 June 1962, ICJ Reports 1962, p. 6, p. 34 ('In general, when two countries establish a frontier between them, one of the primary objects is to achieve stability and finality'). See M. G. Kohen, 'L'influence du temps sur les règlements territoriaux', in Société française pour le droit international, Colloque de Paris: Le droit international et le temps, Paris: Editions A. Pedone, 2001, p. 150; G. Abi-Saab, 'La pérennité des frontières en droit international', Relations Internationales, vol. 64, 1990, pp. 345-6.

${ }_{11}$ T. Pakenham, The Scramble for Africa: The White Man's Conquest of the Dark Continent from 1876 to 1912, London: Weidenfeld \& Nicolson, 1991. In the following I am particularly indebted to Marcelo Kohen for his analysis, see in particular footnotes $10,16,18$ and 28 . 
ance of inherited colonial boundaries by the Organization of African Unity (OAU) in Cairo in $1964 .{ }^{12}$ In 1986, it was coined by the International Court of Justice as a general principle with universal validity. ${ }^{13}$ In the 1990 s it was also applied in Europe, notably in the former Yugoslavia. ${ }^{14}$

A description of the content and origins of uti possidetis juris was given in 1922 by the Swiss Federal Council acting as arbitrator in the Boundary Dispute between Colombia and Venezuela:

\begin{abstract}
When the Spanish colonies of Central and South America proclaimed their independence in the second decade of the nineteenth century, they adopted a principle of constitutional and international law to which they gave the name of uti possidetis juris of 1810. The principle laid down the rule that the boundaries of the newly established republics would be the frontiers of the Spanish provinces which they were succeeding. This general principle offered the advantage of establishing the absolute rule that in law no territory of old Spanish America was without an owner. [. . . Encroachments and ill-timed efforts at colonization beyond the frontiers, as well as occupations in fact, became invalid and ineffectual in law. This principle also had the advantage, it was hoped, of doing away with boundary disputes between new states. Finally it put an end to the designs of colonizing states of Europe against lands which otherwise they could have sought to proclaim as res nullius. The international status of Spanish America was from the very beginning quite different from that of Africa for example. This principle later received general sanction under the name of the Monroe Doctrine, but had long before been the basis of South American public law. ${ }^{15}$
\end{abstract}

The principle setting out the permanence of former colonial territorial divisions to promote territorial integrity and counter colonialism represents the most famous Latin American contribution to international law. ${ }^{16}$ Spanish

12 P. Daillier, M. Forteau and A. Pellet, Droit international public, 8th ed., Paris: LCDJ, 2009, p. 521.

13 International Court of Justice, Frontier Dispute (Burkina Faso v. Republic of Mali), Judgment of 22 December 1986, ICJ Reports 1986, p. 554, p. 565, at para. 205.

14 Conference on Yugoslavia, Arbitration Commission, Opinion No. 3, 11 January 1992, International Legal Materials, vol. 31, 1992, pp. 1497-9; Daillier et al., Droit international public.

15 J. B. Scott, 'The Swiss Decision in the Boundary Dispute between Colombia and Venezuela', American Journal of International Law, vol. 16(3), 1922, pp. 428-31. The quoted paragraph is translated from the French language; Sentence arbitrale $d u$ Conseil Fédéral Suisse sur diverses questions de limites pendants entre la Colombie et le Vénézuéla, Berne, 24 March 1922, Neuchâtel, Imprimerie Paul Attinger, 1922, pp. 5-6; RSA, vol. I, p. 228.

16 M. G. Kohen, 'La contribution de l'Amérique Latine au développement progressif du droit international en matière territoriale', Relations internationales, vol. 139, 2009, p. 13, p. 14; E. J. de Aréchaga, 'Boundaries in Latin America: Uti Possidetis Doctrine', in R. Bernhardt (ed.), Encyclopedia of Public International Law, vol. 1, 
South American territories had been the first to oppose royalist authorities in 1810, starting in Caracas and Buenos Aires, and developing thereafter as a chain reaction across the continent. ${ }^{17}$ The Spanish Central American states refer, on their part, to the end of recognition of Spanish rule in 1821 and Brazil's declaration of independence from Portugal came in 1822, thus establishing later critical dates for the consideration of territorial state succession. ${ }^{18}$

The reception of the concept in international law proved a lengthy journey. Its semantic roots are to be found in Roman law, but the term reappeared with other meanings in other contexts, playing a specific function under the prevailing circumstances in order to resolve a given problem. ${ }^{19}$ In Roman civic law, uti possidetis referred to an interdict against the interference with actual possession. ${ }^{20}$ The term was borrowed and transplanted into an international legal context with the Peace Treaties of Westphalia at the end of the Thirty Years War in 1648. These have been considered as a bridge between Roman law as it had been perceived in the seventeenth century and modern international law. ${ }^{21}$

In an international legal context, as also used by prominent South American publicists, the expression denoted the maintenance of a territorial status quo after armed conflict, i.e. the legal effects of military occupation. ${ }^{22}$

Amsterdam: North-Holland, 1992, p. 449, p. 450; Luis Ignacio Sanchez Rodriguez, 'L'uti possidetis et les effectivités dans les contentieux territoriaux et frontaliers', Collected Courses of the Hague Academy of International Law, vol. 263, 1997, pp. 149-381.

17 J. H. Elliott, Empires of the Atlantic World: Britain and Spain in America 1492-1830, New Haven, CT: Yale University Press, 2006, pp. 379-82.

18 M. G. Kohen, Possession contestée et souveraineté territoriale, Paris: Presses Universitaires de France, 1997, p. 15.

19 M. Troper, 'L'histoire du droit et la théorie générale du droit', in Bernardo Sordi (ed.), Storia e diritto: esperienze a confronto, Atti dell'incontro internazionale di studi in occasione dei 40 anni dei Quaderni fiorentini, Firenze, 18-19 ottobre 2012, Milano: Giuffrè, 2013, p. 387, p. 391. On reception of law, see A. Watson, 'Aspects of Reception of Law', American Journal of Comparative Law, vol. 44(2), 1996, pp. 335-51.

20 References to Roman law in Kohen, Possession contestée, p. 426, note 1 and p. 427 note 3; E. Cantarella, V. Marotta, B. Santalucia, U. Vincenti, A. Schiavone and E. Stolfi, Diritto privato romano - Un profilo storico, Turin: Einaudi, 2003, pp. 278-80. See G. Nesi, 'Uti Possidetis Doctrine', in Max Planck Encyclopedia of Public International Law, 2018, available at http://opil.ouplaw.com/view/10.1093/law: epil/9780199231690/law-9780199231690-e1125.

${ }_{21}$ L. Winkel, 'The Peace Treaties of Westphalia as an Instance of Reception of Roman Law', in R. Lesaffer (ed.), Peace Treaties and International Law in European History: From the Late Middle Ages to World War One, Cambridge: Cambridge University Press, 2004, p. 222, pp. 229-35 (in particular p. 232).

22 C. Calvo, Derecho Internacional Téorico y Práctico de Europa y América, Paris: Amyot, Durand, Pedone-Lauriel, 1868, vol. II, p. 129. 
This had remarkably little to do with respect for inherited title in the form of administrative boundaries after state succession. ${ }^{23}$ Its use by Spanish American diplomats was decisive, albeit leading to some confusion. ${ }^{24}$ For instance Arnold McNair made no use of the concept when, as late as in 1961, he described developments relating to the independence of new states in Spanish South America. ${ }^{25} \mathrm{He}$ appears only to have analysed uti possidetis in the context of Roman law, in which he incidentally was proficient. ${ }^{26}$

The current use of the term was introduced by diplomats in negotiations, referring to the inheritance of the administrative boundaries established by the former colonial power. Rather than signifying a subservience to the authority of colonial European powers or a legal crossover to colonial law, reliance on inherited boundaries became a rampart against foreign powers' intervention. As consecrated by the Swiss Federal Council acting as Arbiter in 1922, the term thus stemmed from Spanish American states referring to uti possidetis juris, with an emphasis on 'the Latin genitive juris'. This established that there was no terra nullius on the American continent, and thus no basis for occupation by non-American powers, and secondly, recognition of pre-existing administrative limits:

There are several different aspects to this principle, in its well-known application in Spanish America. The first aspect, emphasized by the Latin genitive juris, is found in the pre-eminence accorded to legal title over effective possession as a basis of sovereignty. Its purpose, at the time of the achievement of independence by the former Spanish colonies of America, was to scotch any designs which non-American colonizing powers might have on regions which had been assigned by the former metropolitan State to one division or another, but which were still uninhabited or unexplored. However, there is more to the principle of uti possidetis than this particular aspect. The essence of the principle lies in its primary aim of securing respect for the territorial boundaries at the moment when independence is achieved. Such territorial boundaries might be no more than delimitations between

23 Ibid.: 'El titulo de posesion del territorio conquistado se completa, bien por un tratado de paz, ya por provisiones expresas, bien en vertud del uti possidetis. Cuando la cesion se establece por pacto expecial, es costumbre muy general requerir las condiciones mas ventajosas posibles para los habitantes del territorio. Igual cumplida confirmacion recibe el titulo á poseer del conquistador si se fija en un tratado general de paz, porque como su base es el uti possidetis, á no ser que se exprese el contrario, el territorio conquistado permanece con él y no puede, en manera alguna, dudarse de la validez de un titulo adquirido así.'

24 Kohen, Possession contestée.

25 A. McNair, The Law of Treaties, Oxford: Oxford University Press, 1961, pp. 601-3, as opposed to, for instance, Herbert Briggs, The Law of Nations: Cases, Documents and Notes, 2nd ed., London: Stevens and Sons, 1953, p. 262.

26 W. W. Buckland and A. D. McNair, Roman Law and Common Law, 2nd ed. (rev. by F. H. Lawson), Cambridge: Cambridge University Press, 1965, pp. 63, 141 and 394. 
different administrative divisions or colonies all subject to the same sovereign. In that case, the application of the principle of uti possidetis resulted in administrative boundaries being transformed into international frontiers in the full sense of the term. ${ }^{27}$

This Spanish American conception has been contrasted with the Brazilian doctrine of uti possidetis, formulated without the Latin genitive juris (or sometimes referred to as uti possidetis de facto). However, it has been shown that this difference has been exaggerated.$^{28}$ Brazil did not negate uti possidetis juris as applicable to pre-existing or colonial administrative frontiers within the same empire or sovereign, i.e. to Spanish America. In other cases, applicable treaties might resolve the issue. In the absence of such legal title, including where Brazil had denied the continued existence of treaties in force, Brazil would then rely on evidence of effective possession. As Brazil's foreign minister José Maria da Silva Paranhos Jr., Baron of Rio Branco, explained to his Ecuadorian colleague Carlos Tobar:

Uti possidetis is the rule that we observe in our conventional relations with neighbouring States, instead of the one known as uti possidetis juris which may only be applied in negotiations on limits between Spanish American states, as these correspond to the ancient territorial divisions and are drawn by the same authorities. ${ }^{29}$

Thus, Brazil and the Spanish American states shared in reality more than a few fundamental conceptions. ${ }^{30}$ There was agreement that, at the beginning of the nineteenth century, no terrae nulliae existed in South America. No such territories could therefore be occupied by non-American colonial powers. Moreover, new states had succeeded to the territorial sovereignty of Spain and Portugal. Furthermore, where frontier treaties concluded with colonial powers were still in force, these would be applied to define the borders with the newly independent states, as was the case for instance with France as regards French Guyana. ${ }^{31}$ There are therefore few fundamental differences as to the theoretical

27 ICJ Reports 1986, p. 566, at para. 23.

28 M. G. Kohen and K. Del Mar, 'Decolonization in Latin America: Its Trail-Blazing Role for Decolonization in Other Parts of the World', in C. Auroi and A. Helg, Latin America 1810-2010: Dreams and Legacies, London: Imperial College Press, 2012, p. 43, p. 50; Kohen, 'La contribution de l'Amérique Latine', p. 18.

${ }_{29}$ Rio Branco, 'Letter to Ecuador's Foreign Minister Carlos Tobar, Antônio A. Cançado Trindade', Repertôrio da Prática Brasileira do Direito Internacional Público (Período 1899-1918), Brasilia: Fundaçao Gusmão, 1986, vol. I, p. 265, quoted in French by Kohen, 'La contribution de l'Amérique Latine', p. 18, note 12.

30 Kohen, 'La contribution de l'Amérique Latine', p. 18.

31 Arbitral Award relating to the question of the boundaries between Brazil and French Guyana, RIAA, 1 December 1900, vol. XXVIII, pp. 349-78, 2007. 
underpinnings of the legal approach taken in South America. ${ }^{32}$ In this context, the role of the baron of Rio Branco (1845-1912) stands out. ${ }^{33}$ As a diplomat and later foreign minister of Brazil (1902-12), he was a key architect of Brazil's peaceful settlement of a considerable number of outstanding border issues through treaty negotiations and arbitration. ${ }^{34}$

A deep undercurrent in the modern history of international law has been the consolidation of the principle of stability of borders after state succession, thus contributing to maintain international peace and security. Rosalyn Higgins, quoting Judge Ad hoc Abi Saab, has also observed that without the stability of frontiers, the exercise of self-determination is in reality a mirage. ${ }^{35}$ The maintenance of territorial status quo by the Organization of African Unity in 1964 was a major step in this direction as confirmed by the International Court of Justice:

At first sight this principle conflicts outright with another one, the right of peoples to self-determination. In fact, however, the maintenance of the territorial status quo in Africa is often seen as the wisest course, to preserve what has been achieved by peoples who have struggled for their independence, and to avoid a disruption which would deprive the continent of the gains achieved by much sacrifice. The essential requirement of stability in order to survive, to develop and gradually to consolidate their independence in all fields, has induced African States judiciously to consent to the respecting of colonial frontiers, and to take account of it in the interpretation of the principle of self-determination of peoples. ${ }^{36}$

The dynamics behind these momentous developments and the role of actors that influence state action and production of norms in this context may deserve

32 Kohen and Del Mar, 'Decolonization in Latin America', p. 51; Kohen, Possession contestée, pp. 448-49.

33 A. G. de A. Jorge, Rio Branco e as Fronteiras do Brasil (Uma introdução às obras do Barão do Rio Branco), Brasília: Senado Federal, 1999. On the role of the Brazilian lawyer Ruy Barbosa de Oliveira (1849-1923) and his relations with Rio Branco, see J. Fischel de Andrade and D. Limoeiro, 'Rui Barbosa e a política externa brasileira: considerações sobre a Questão Acreana e o Tratado de Petrópolis (1903)', Revista Brasiliera de Politica Internacional, vol. 46(1), 2003, pp. 94-117.

34 There appears to be a discrepancy between Brazil's celebration of this diplomat, and the limited analysis in the history of international law of his contributions, including to the peaceful resolution of disputes and the maintenance of international peace and security. The Diplomatic Institute of the Brazilian Foreign Ministry is incidentally also named Instituto Rio Branco, http://www.institutoriobranco.itamaraty.gov.br/ historia.

35 R. Higgins, Problems and Process: International Law and How We Use it, Oxford: Clarendon Press, 1994, pp. 122-4.

36 ICJ Reports 1986, p. 567, at para. 26. 
further scrutiny. So does the role of legal concepts in negotiations and their evolution within a given legal context.

The Latin expression uti possidetis projects semantically the idea of preserving something inherited from the past, with the aim of contributing to stability and predictability. As such, it may be vaguely related to rebus sic stantibus, i.e. as things stand. There are rich traditions of utilizing phrases stemming from the language of Roman law in various receptions of patterns of thought in the history of law and utilizing them in a different legal context with adaptations. ${ }^{37}$ With Roman law's aspirations as a universal legal order, later inherited by the canonic legal order, also using Latin, it may come as no surprise that problem-solving in international law often attempted to draw legitimacy through such authority. Prominent examples of international law pioneers who relied heavily on historical analysis with use of Roman legal concepts, adapted to their ongoing work as problem-solving practitioners, include Hugo Grotius and Carlos Calvo. ${ }^{38}$

Critical analysis has drawn on history, deconstructing legal norms and process, leading to a discussion of the determinacy of international law. ${ }^{39}$ There may, however, also be scope for studying further the process of construction of legal concepts within a legal system, which is something different than undertaking a history of evolution of concepts in international law. ${ }^{40} \mathrm{It}$ may reveal the creative forces, institution building and actors that contribute to

37 M. Stolleis, 'Il Quadro Europeo', in B. Sordi (ed.), Storia et Diritto, Esperienze a Confronto, Atti dell'incontro internazionale di studi in occasione dei 40 anni dei Quaderni Fiorentini, Florence, 18-19 October 2012, Milan: Giuffrè, 2013, pp. 36-8; F. Calasso, Introduzione al Diritto Comune, Milan: Giuffrè, 1951; F. Calasso, I Glossatori e la Teoria della Sovranità, Studio di diritto comune pubblico, 2nd ed., Milan: Giuffrè, 1951.

38 Both the Dutch and the Argentinian theorists were also practitioners, incidentally, having served in different centuries in diplomatic postings in Paris. The two following works are heavily influenced by historical analysis: Hugo Grotius, Mare Liberum (1609) (translated into English by Richard Hakluyt as The Free Sea, in D. Armitage (ed.), Natural Law and Enlightenment Classics, Indianapolis: Liberty Fund, 2004); C. Calvo, Derecho Internacional Téorico y Práctico de Europa y América, Paris: D’Amyot, 1868 ( $§ 1$. 'La importancia del derecho internacional en la ciencia general del derecho se reflecha también en la historia del mismo derecho internacional [...]'; §2. 'En esta primera época el derecho internacional se nos ofrece dominado por la idea religiosa ó por las formulas del derecho romano [. . . ]').

39 M. Koskenniemi, From Apology to Utopia: The Structure of International Legal Argument (Cambridge: Cambridge University Press, 1989), and The Gentle Civilizer of Nations: The Rise and Fall of International Law 1870-1960 (Cambridge: Cambridge University Press, 2001) provide two examples.

40 Troper, 'L'histoire du droit et la théorie générale du droit', p. 391. See his references, including M. Bloch, Apologie pour l'histoire du métier d'historien, Paris: Armand Colin, 1949, p. 12. 
such determinacy of law. The cursory references made to the notion of uti possidetis may provide ammunition to the assessment made by Quentin Skinner, inspired notably by Wittgenstein and J. L. Austin, that:

one of the most important of the many injunctions contained in Wittgenstein's Philosophical Investigations is that we ought not to think in isolation of 'the meanings of words'. We ought rather to focus on their use in specific language-games and, more generally, within particular forms of life. ${ }^{41}$

The famous sentence 'the meaning of a word is its use in the language' is an inspiration to identify and document actual uses of terms in the specific language-games utilized between states, on the basis of their ordinary use in the relevant contexts. ${ }^{42}$ This links up perfectly with the general rule of interpretation set out in the Vienna Convention on the Law of Treaties in 1969 article 31 , as regards the 'ordinary meaning' to be given to the terms of a treaty and other accepted means of interpretation of the treaty. In the context of uti possidetis juris, as highlighted by Judge Ad hoc Abi Saab in the 1986 judgment of the International Court of Justice:

this principle, like any other, is not to be conceived in the absolute; it has always to be interpreted in the light of its function within the international legal order. ${ }^{43}$

The generic content and the stability of key components of this principle were thus provided primarily by Latin American and then by African states.

\section{FROM OUTRIGHT REJECTION OF INTERNATIONAL LAW AS A MERE CAPITALIST AND IMPERIALIST TOOL TO GRADUAL ADAPTATION TO THE INTERNATIONAL LEGAL SYSTEM}

As noted by Crawford, since the mid-nineteenth century the only serious attempt on the part of a major state to reject and abandon international law was that of the Russian Socialist Federative Soviet Republic after the Bolshevik

\footnotetext{
41 Q. Skinner, Visions of Politics: Regarding Method, vol. I, Cambridge: Cambridge University Press, 2002, p. 103; L. Wittgenstein, Philosophische Untersuchungen. Philosophical Investigations, translated by G. E. M. Anscombe, Oxford: Blackwell Publishing (first published 1958), 3rd ed., 2001, pp. 46-7, at paras. 138-9, and p. 68, at paras. 197-8; J. L. Austin, How to Do Things with Words, 2nd ed. (ed. J. O. Urmson and M. Sbisà), Cambridge, MA: Harvard University Press, 1980, pp. 94-8. It is enlightening to consider translations, as they may denote approaches to interpretation.

${ }_{42}$ Wittgenstein, Philosophical Investigations, p. 18, at para. 43.

43 ICJ Reports 1986, Separate Opinion of Judge Abi-Saab, p. 111, at para. 13.
} 
Revolution of 1917 and, after its foundation in 1922, that of the early Soviet Union. ${ }^{44}$ This rejection was, in the words of Anand, based on a 'conflicting and aggressive ideology which sought to repudiate many of the values and institutions shared by the Western countries'. ${ }^{45}$ Early Soviet lawyers had largely dismissed international law as a part of the superstructure of law, an attribute of the foreign policy of states and an expression of the will of the ruling class. ${ }^{46}$ They were inspired by the international law theorist Evgeny Pashukanis (1891-1937), who provided the main theoretical underpinnings of this Marxist critique. ${ }^{47}$ Influential Soviet protagonists later included Andrey Vyshinsky (1883-1954) and Evgeny A. Korovin (1892-1964), who came to represent a strict positivist approach based on new treaties, dismissing the universal roots and architecture of international law. ${ }^{48}$

However, Soviet formal legal positions were not static. They evolved from initial rejection of a universal system of international law to a gradual engagement in its codification and progressive development, albeit to be mustered to promote Soviet political goals. As opposed to common reduction of Soviet schools of international law to one of the 'most important historical examples of regional approaches to international law', ${ }^{49}$ a neglect of Marxist and Soviet theories in the wake of the dismantlement of the Berlin Wall has rightly been ascribed to a limited knowledge of these theories in the West. ${ }^{50}$

44 J. Crawford, 'Chance, Order, Change: The Course of International Law', Collected Courses of the Hague Academy of International Law, vol. 365, 2013, pp. 407-8 and 235-6.

45 R. P. Anand, Confrontation or Cooperation? International Law and the Developing Countries, New Delhi: Banyan Publications, 1986, p. 33.

46 Higgins, Problems and Process, p. 11.

47 E. B. Pashukanis, 'The General Theory of Law and Marxism', in P. Beirne and R. Sharlet (eds.), Evgeny Pashukanis: Selected Writings on Marxism and Law, London and New York: Evgeny Pashukanis, 1980; V. Vereschetin and R. Mullerson, 'International Law in an Interdependent World', Columbia Journal of Transnational Law, vol. 28(1), 1990, p. 291; Crawford, 'Chance, Order, Change', p. 408.

48 E. Korovin, 'La république des Soviets et le droit international', Revue générale de droit international public, vol. 32, 1925, p. 292. E. McWhinney, 'Soviet Bloc Publicists and the East-West Legal Debate', Canadian Yearbook of International Law, vol. 2(1), 1964, pp. 172-83. B. Bowring, 'Positivism Versus Self-Determination: The Contradictions of Soviet International Law', in S. Marks (ed.), International Law on the Left: Re-examining Marxist Legacies, Cambridge: Cambridge University Press, 2008, pp. 133-68.

${ }^{49}$ A. Peters, 'International Scholarship under Challenge', in J. D'Aspremont, T. Gazzini, A. Nollkaemper and W. Werner (eds.), International Law as a Profession, Cambridge: Cambridge University Press, 2017, p. 120.

50 A. Bianchi, International Law Theories: An Inquiry into Different Ways of Thinking, Oxford: Oxford University Press, 2016, p. 74. See also T. Långström, Transformation in Russia and International Law, Leiden: Martinus Nijhoff, 2003; 
Grigorii I. Tunkin (1906-93) played a particular role in this context. ${ }^{51}$ He was born in Archangelsk in the Russian Arctic in 1906, distinguished himself academically, and served as a diplomat, notably in Iran during the Second World War and on the Korean Peninsula at the end of hostilities in the Korean War. As the legal adviser of the Soviet foreign ministry (1952-65), he incarnated Soviet international legal argument during large parts of the Cold War. He represented the Union of Soviet Socialist Republics at the United Nations, in bilateral intergovernmental negotiations, as an influential teacher for a generation of Russian and other socialist students and a prolific publicist quoted in most treatises describing competing world views of international law. Significantly, he became an active member of the International Law Commission, becoming its president in 1961 and participating notably in the codification of the law of treaties and a broader international discourse of sources of international law. ${ }^{52}$ The evolution in Soviet formal legal positions, as expressed by Tunkin, cannot merely be dismissed as a function of changing political circumstances. It also denoted an increased role and refinement of formal legal argument in international policy formulation by the Soviet Union, arguably influenced by considerations of utility as regards diplomatic multilateral persuasion, but also by an ambition of individuals to better satisfy criteria of scientific method. Tunkin may thus be said to have contributed to a turn in Soviet legal argument, including through his course at The Hague Academy of

J. Quigley, 'Perestroika and International Law', American Journal of International Law, vol. 82(4), 1988, pp. 788-9; J. Quigley, 'The New Soviet Approach to International Law', Harvard International Law Club Journal, vol. 7(1), 1965, pp. 1-2; L. Mälksoo, Russian Approaches to International Law, Oxford: Oxford University Press, 2015.

51 Grigorii Ivanovich Tunkin (1906-93). From 1939 with the Ministry of Foreign Affairs. Soviet consul in Gorgan (Iran). 1948-51 and 1951-52 Minister-Counsellor of the Soviet Embassy in the Korean People's Democratic Republic. Doctoral dissertation in 1954: 'The Korean Problem After the Second World War in the Light of International Law'. From 1952 to 1965 head of the legal section of the Ministry of Foreign Affairs. See G. I. Tunkin, Theory of International Law (translated with an introduction by W. E. Butler and edited by W. E. Butler, L. N. Shestakov, The Vinogradoff Institute, University College London), 2nd ed., London: Wildy, Simmonds and Hill Publishers Ltd., 2003. Theory of International Law was published in an English version in 1974, based on the Russian 1970 edition, and reissued in 2003.

52 R. Mullerson, 'Obituary: Professor Grigory Tunkin', The Independent, 28 August 1993. Mullerson's obituary contrasts with the book review by M. Akehurst, Theory of International Law. By G. I. Tunkin (translated from the Russian, with an introduction, by William E. Butler). London: George Allen \& Unwin, 1974, British Yearbook of International Law, vol. 47(1), 1976, p. 496, which referred to a 'strange mixture of first-rate legal argument and crude propaganda'. 
International Law in 1956 and a treatise of international law that appeared in different editions and was translated into other languages. ${ }^{53}$

After the thaw following Stalin's death in 1953, he opposed Korovin's and Vyshinsky's approaches, unequivocally recognizing the existence of a separate international legal system:

For thousands of years jurists have debated about definitions of law, but notwithstanding this law has existed. States, politicians, and jurists of different countries can hold various theories relating to the nature of international law, but this difference of opinion does not create insuperable obstacles to achieving agreements relating to the acceptance of specific rules of conduct as international legal norms. ${ }^{54}$

He enlisted the authority of Pashukanis, when recalling '[s]ince States have no higher authority above them which would establish norms of conduct for them, the sources of international law in the technical juridical sense of the word are custom and treaty'. On this basis, he took as did other Soviet lawyers a restrictive positivist approach to international law, recognizing treaties and customary international law, emphasizing however the integrity of this legal system. In so doing, he advocated a strictly voluntarist approach to international law, both as regards treaties and customary law:

The process of concluding an international treaty is the process of bringing the wills of States into concordance, the result of which is an agreement that is embodied in the norms of the treaty.

It should be pointed out that the process of forming a customary norm of international law, just as a treaty norm, is the process of the struggle and cooperation of States. The formulation of a customary rule occurs as a result of the intercourse of States, in which each State strives to consolidate as norms of conduct those rules which would correspond to its interests.

A rule of conduct which is the result of general practice [ . . ] becomes a customary norm of international law only when it is accepted or recognized by States as legally binding, as a norm of law. ${ }^{55}$

Confirming an allegiance to a superior system of international law, based on a principle of pacta sunt servanda, he served Soviet foreign policy interests by paving the way for a legal basis for the elaboration of the concepts of

53 Långström, Transformation in Russia and International Law, p. 92. See also Bianchi, International Law Theories. G. Tunkin, 'Co-Existence and International Law', Collected Courses of The Hague Academy of International Law, vol. 95(1), 1956, pp. 5-78.

${ }_{54}$ G. I. Tunkin, Theory of International Law (translated by William E. Butler), Cambridge, MA: Harvard University Press, 1974, p. 48.

55 Ibid., pp. 214, 114 and 127. 
peaceful coexistence and self-determination of peoples. ${ }^{56}$ As noted by Higgins, there was 'an operational agreement on the existence of international law as a system' and '[w]here the will of the ruling classes of the socialist and capitalist systems coincided, international law could exist'. ${ }^{57}$ As a member of the International Law Commission from 1957 to 1966 Tunkin was involved in the deliberations leading to the adoption of the Vienna Convention on the Law of Treaties in 1969. Characteristically for his approach, he is for instance quoted as stating:

14. Mr. TUNKIN said that the pacta sunt servanda rule should be stated concisely and in precise terms [...] The rule was, in his opinion, of much wider application than the law of treaties, as agreement between States underlay every norm of international law. ${ }^{58}$

Acknowledging the role of foreign policy in international law, he also referred to the influence of international law on foreign policy and diplomacy: ${ }^{59}$ 'International law, just as national law, influences the social relations which it regulates'. He disputed McDougal's and other realists' conception that international law merely merges into politics. Tunkin spoke in favour of law as a social phenomenon, distinct from politics. ${ }^{60}$ His participation in the formulation of the rules of treaty law contributed to consolidating international law as a grammar for international relations, advocating its codification and

56 Bowring, 'Positivism Versus Self-Determination'; N. S. Khrushchev, 'On Peaceful Coexistence', Foreign Affairs, vol. 38(1), 1959, pp. 1-18; S. B. Krylov, 'Les notions principales du droit des gens: la doctrine soviétique du droit international', Collected Courses of The Hague Academy of International Law, vol. 70(1), 1947, pp. 415-74; V. P. Karpov, 'The Soviet Concept of Peaceful Coexistence and its Implications for International Law', in H. W. Baade (ed.), The Soviet Impact on International Law, New York: Oceana Publications, 1965, pp. 14-20; W. Lerner, 'The Historical Origins of the Soviet Doctrine of Peaceful Coexistence', Law and Contemporary Problems, vol. 29(4), 1964, pp. 865-70; R. St. J. Macdonald, 'The Idea of Peaceful Co-Existence: Then and Now', in E. Yakpo and T. Boumedra (eds.), Liber Amicorum: Mohammed Bedjaoui, The Hague: Kluwer Law International, 1999, pp. 201-10.

57 Higgins, Problems and Process, p. 11.

58 International Law Commission, Summary records of the sixteenth session 11 May-24 July 1964, Law of Treaties, 727th meeting of 20 May 1964, Yearbook of the International Law Commission, vol. I, 1964, p. 27, at para. 14 (UN Docs. A/CN.4/167 and A/CN.4/SERA/1964).

59 Tunkin, Theory of International Law, pp. 304-18.

60 G. I. Tunkin, Droit international public, Problèmes théoriques (translated into French on the basis of the Russian 1962 edition), Paris: Editions A. Pedone, 1965, p. 190. G. I. Tunkin (ed. Theodor Schweisfurth), Völkerrechtstheorie (translated into German on the basis of the 1970 Russian edition), Berlin: Verlag, 1972, p. 336. 
progressive development. At the same time, he 'enlisted' international law also to play a role in international relations, including combating colonialism. ${ }^{61}$

Tunkin personifies an important moment of political consolidation of international law, which might also be studied from the perspective of a phenomenon of broader reception of international law. He contributed to formulating a grammar that changed the Soviet legal discourse embracing established international law, while linking it to a socialist and Soviet political programme of action. It promoted the principle of self-determination of peoples, first as a reference advanced by the Soviet Union in 1945 and included in the United Nations Charter, and later included on a Soviet initiative in the Decolonization resolution $1514(\mathrm{XV})$ of 14 December $1960 .{ }^{62}$

Broadening the scope of reflection, one can detect here broader phenomena of reception of international law. These have arguably come at a time that largely coincided with decolonization and choices made by newly independent states embracing, while criticizing the content of, international law. Thus, Higgins has found it striking that there is no suggestion by emergent countries that they are not bound upon independence by international law as a whole, even if its formation owed much to Western European history. ${ }^{63}$

\section{THE EMERGENCE OF 'SUPRANATIONAL' INSTITUTIONS}

The Schuman plan of 9 May 1950 established the vision of European integration to build peace in Europe. As a first step it envisaged the establishment of a High Authority for coal and steel. The plan was announced by foreign minister Robert Schuman in the Salon de l'horloge of the French foreign ministry, almost to the day, five years after the armistice on 8 May 1945 of the Second World War. Inspired and coordinated by the visionary Jean Monnet, it is widely referred to as the Monnet plan. ${ }^{64}$ Setting the foundations for sharing sovereign powers through a common supranational organ, the High Authority, it provided the institutional origins, or the keystone, of the future European Commission and European integration. ${ }^{65}$

\footnotetext{
${ }_{61}$ Tunkin, Theory of International Law, p. 259.

62 Bowring, 'Positivism Versus Self-Determination', p. 135.

63 Higgins, Problems and Process, p. 12, with reference to B. Verzijl, 'Western European Influence on the Foundation of International Law', International Relations, vol. 1(4), 1955, pp. 137-46.

64 E. Roussel, Jean Monnet 1888-1979, Paris: Fayard, 1996, pp. 528, 553.

65 C. Blumann and L. Dubouis, Droit institutionnel de l'Union européenne, 6th ed., Paris: LexisNexis, 2016, p. 5, at para. 10; G. Bebr, 'The European Coal and Steel
} 
Monnet himself, however, credited the lawyer Paul Reuter (1911-90) not only for conceiving the institutional mechanism of the authority, but also for its name. ${ }^{66}$ André Gros who was elected to the International Court of Justice in 1964, has described Reuter's key role in the team of advisers assembled round Jean Monnet 'at the stage of a white page' or of a 'legal vacuum'. ${ }^{67}$ The Frenchman Reuter was born in 1911 in the city of Metz, then under German administration, five years after the birth of Grigorii Tunkin. He became a member of the International Law Commission in 1964, towards the end of Tunkin's membership, contributing notably to the codification of the law of treaties.

His contributions to the development of new international institutions coincided with the launch of the debate on the concept of 'supranational' organs. ${ }^{68}$ Reuter set out the three essential elements for such organs. They had to be independent in respect of national governments, which was not something new, but the independence encompassed a broader scope of competencies. The transfer of such competencies, combined with the setting in common of them, could be seen as the result of a partial fusion of national powers, thereby making it possible to talk of a 'Community'. ${ }^{69}$ The third element is the emergence of direct relations between the Community's organs and individuals, contrary to traditional international law. ${ }^{70}$

Community: A Political and Legal Innovation', Yale Law Journal, vol. 63(1), 1953, p. 1.

${ }_{66}$ 'Toujours est-il que Paul Reuter fut à l'origine de la Haute Autorité, du mot comme de la chose.' J. Monnet, Mémoires, Paris: Fayard, 1976, p. 431.

67 A. Gros, 'Hommage au professeur Paul Reuter', in Le droit international, unité et diversité: mélanges offerts à Paul Reuter, Paris: Pedone, 1981, p. 6. See similarly F. Roth, Robert Schuman 1886-1963. Du Lorrain des frontières au père de l'Europe, Paris: Fayard, 2008, pp. 383-6 and 528. A critical analysis is provided by A. Cohen, 'Le plan Schuman de Paul Reuter. Entre communauté nationale et fédération européenne', Revue française de science politique, vol. 48(5), 1998, pp. 645-63.

68 P. Reuter, La Communauté européenne du charbon et de l'acier, Paris: LGDJ, 1953, pp. $138-40$, at paras. $140-143$.

${ }^{69}$ Ibid., p. 139, at para. 142.

70 P. Reuter, Les interventions de la Haute autorité. Rapport présenté au Congrès international d'études sur la Communauté européenne du charbon et de l'acier, IVème commission scientifique internationale, Centre italien d'études juridiques, Milan: Giuffrè, 1957, pp. 72-5. R. Monaco, 'Le Comunità Sopranazionali nell'Ordinamento Internazionale', in R. Monaco, Scritti di diritto europeo, Milan: Giuffrè, 1972, pp. $47-75$. 


\section{THE DANGER OF ANACHRONISMS}

Having considered three moments of the history of international law that marked periods of deep consolidation or transformation, a first word of caution concerns transposition of legal terms or concepts out of their legal context. In his classic introduction to Roman law, Barry Nicholas reminded us for example that:

The Romans often declare that possession is a fact, and this has given rise to some debate among modern jurists, who commonly prefer to see it as a right. There is, however, a danger of being bemused by words unless one inquires first what the Romans meant by possession as a fact. And one should perhaps begin with what they did not mean. ${ }^{71}$

This type of caution could be applicable to the interpretation of concepts in international law, and reflects issues of method relating to interpretation and identification of context, as shown by the International Court of Justice in 1986, and supported by Quentin Skinner's reflections concerning the history of ideas.

Both the historian and the lawyer may benefit from the admonition of Marc Bloch, and his comparison with the investigative magistrate:

Before interpreting a phenomenon, the latter must be discovered. [. . .] [Someone may ask maybe,] is there really a need to go to all this trouble to 'discover' historic facts? They are only known to us and recognizable through documents; [. . .] isn't it sufficient to read texts or documents? Undoubtedly, but on condition that one is able to read them. A document is like a witness; as most witnesses, it won't speak unless interrogated. The challenge is thus to formulate the right questions. This is where comparisons provide precious support to the ceaseless investigative magistrate that a historian actually is. ${ }^{72}$

\section{CHALLENGES RELATING TO SOURCES}

A basic dependence on primary sources and their interpretation is common to both history and international law. The two disciplines' success criteria and legitimacy are in large part linked to this double dependence.

\footnotetext{
71 B. Nicholas, An Introduction to Roman Law, Oxford: Clarendon Press, 1962, p. 114.

${ }^{72}$ M. Bloch, 'Pour une histoire comparée des sociétés européennes', in M. Bloch, L'Histoire, la Guerre, la Résistance, Paris: Quarto Gallimard, 2006, pp. 353-4 (translation from the French into English by the author). See also M. Bloch, The Historian's Craft, New York: Vintage Books, 1954.
} 
Interpretation is the central mode of understanding in both disciplines. As such, these involve different hermeneutical processes, but often overlap, without being absorbed into each other. The development of international law has gone along with historical narratives leading to the identification of authoritative sources and derived chains of authority. This has contributed to the construction of legitimacy.

As opposed to historians, international lawyers take decisions to ensure finality and determinacy as regards legal questions (pacta sunt servanda, res judicata, etc.). In so doing, they rely on authority as regards interpretation, based on formal criteria and a definition of relevant sources, and they build on a relationship between concepts of law and legal institutions. ${ }^{73}$ Moreover, in some cases, international lawyers may create new primary sources and negotiate the creation of new institutions. Historians cannot do either. On the other hand, they are thoroughly unconstrained by formal authority in terms of past interpretation. Being mainly bound by the authenticity of original primary sources or data, historians are instead engaged in a ceaseless reappraisal, reformulation and redefinition of questions, premises and perspectives. Where the international lawyer strives for justice relying on rule-based impartial determination and predictability, the historian is engaged in Sisyphean uncovering of meaning, either as 'parachutists' or as 'truffle hunters', to quote Le Roy Ladurie. ${ }^{74} \mathrm{Or}$, as suggested by Berlin, either as a 'fox that knows many things' or 'the hedgehog that knows one big thing'. ${ }^{75}$

While the historian's endeavours may lead to interpretive pluralism, the international lawyer puts emphasis on continuity and authority. ${ }^{76}$ Thus, contemporary international law strives for coherence and order in a complex world with an increasing variety of recognized institutions and stakeholders. ${ }^{77}$ This

73 N. MacCormick, Legal Reasoning and Legal Theory, Oxford: Oxford University Press, 1978; N. MacCormick, Institutions of Law: An Essay in Legal Theory, Oxford: Oxford University Press, 2007.

74 E. Le Roy Ladurie, Paris-Montpellier PC-PSU 1945-1963, Paris: Gallimard, 1982, pp. 207-8, as quoted by J. H. Elliot, History in the Making, New Haven, CT: Yale University Press, 2012, p. 197.

75 In philosophy, an analogy may be drawn to the distinction between the working methods of a hedgehog and a fox. See I. Berlin, The Hedgehog and the Fox: An Essay on Tolstoy's View of History, London: Weidenfeld \& Nicolson, 1953.

76 J. Raz, Between Authority and Interpretation: On the Theory of Law and Practical Reasons, Oxford: Oxford University Press, 2009, pp. 231-2.

77 R. Dworkin, Justice for Hedgehogs, Cambridge, MA: Harvard University Press, 2011. 
may be described as a reason-driven striving against fragmentation, including through systemic integration. ${ }^{78}$

History may, at all stages, contribute particular insights into international law, its emergence, context and sometimes contents, and vice versa. ${ }^{79}$ The history of international relations may have underestimated the role of international law, as regards development of international politics on a variety of levels. ${ }^{80}$

Moreover, the exercise of a variety of roles in the context of international law may require high-intensity identification and interpretation of historical facts, which often relies on documentary evidence and a critical approach to primary sources. This may not least be an important feature of legal process in the resolution of territorial issues, whether through treaty negotiations or third-party settlement. Different questions arise in judicial fact-finding in the context of armed conflict or atrocities, where the mapping of social and political structures, chains of civil or military command or knowledge, may require collection and assessment of vast amounts of evidence. Those examples differ from the roles of the historian.

\section{REFLECTIONS ON HISTORY AND INTERNATIONAL LAW: REASONS TO TAKE AN INTEREST}

There is a variety of different reasons to take an interest in history when dealing with international law. And, inversely, international law ought to interest historians, albeit for a range of different reasons. ${ }^{81} \mathrm{~A}$ third issue concerns the questions raised in history of international law, which has matured into a distinct discipline, mushrooming in different directions often under the influence of broader philosophical approaches, including critical theory. I have in this chapter attempted to take the long view reflecting on particular moments of change or consolidation of international law, where legal argument inter-

78 M. Koskenniemi, 'Fragmentation of International Law: Difficulties arising from the Diversification and Expansion of International Law', Report of the Study Group of the International Law Commission, UN Doc. A/CN.4/L.682, 13 April 2006.

79 An example is the historical analysis of constitutional and international law in the case Legal Status of Eastern Greenland (Denmark v. Norway), Judgment of 5 April 1933, Permanent Court of International Justice, Series A/B, No. 53. See R. E. Fife, 'Legal Status of Eastern Greenland (Denmark v Norway) (1933)', in E. Bjørge and C. Miles, Landmark Cases in Public International Law, London: Hart Publishing, 2017, pp. 133-57.

80 Fife, 'Legal Status of Eastern Greenland (Denmark v Norway) (1933)', pp. 133-4.

${ }_{81}$ L. Schapiro, 'The Importance of Law in the Study of Politics and History', in E. Dahrendorf (ed.), Russian Studies, New York: Penguin Books, 1986, pp. 29-44. 
acted in a decisive manner with political change, and in so doing influenced in depth the further course of events.

Of particular interest are situations where international legal arguments as such may have proved decisive at political levels, and had lasting influence on the course of history. A key question may be how acceptance or actual endorsement of legal rules or institutions established by other states came to be perceived to be in the national interest - and how they in fact were taken on board, contributing to what with hindsight may be considered a systemic shift. Consequentialist arguments may play a decisive role at the stage of drafting or negotiating new legal instruments or approaches. ${ }^{82}$

Historians of law are familiar with the concept of 'reception' of legal systems, norms, concepts or patterns of thought - which could mean adopting a broader concept or drawing ideas from a different legal system. The three moments described shed light on how broader reception, in a historical sense, may take place. Might this provide a different lens to situate future issues or trends in the history of international law?

82 On consequentialist arguments, see MacCormick, Legal Reasoning and Legal Theory, pp. 129-51. 